NBER WORKING PAPER SERIES

\title{
PEER EFFECTS IN HIGHER EDUCATION
}

Gordon C. Winston

David J. Zimmerman

Working Paper 9501

http://www.nber.org/papers/w9501

\author{
NATIONAL BUREAU OF ECONOMIC RESEARCH \\ 1050 Massachusetts Avenue \\ Cambridge, MA 02138 \\ February 2003
}

We want to thank Atlantic Philanthropic Services and especially the Andrew W. Mellon Foundation for its continuing support of the Williams Project on the Economics of Higher Education and for making their unique College and Beyond data set available for this study. Jared Carbone, Al Goethals, Georgi Zhelev, and Adam Sischy contributed a good deal to the chapter while Caroline Hoxby went way beyond the usual volume editor in her interest in and contribution to the work. Finally, the participants in Project working lunches, a Williams Economics Department seminar and the NBER seminar at Bretton Woods - especially Tom Dee - were very helpful in spotting ambiguities and dubious assertions in an earlier draft. The views expressed herein are those of the authors and not necessarily those of the National Bureau of Economic Research.

(C)2003 by Gordon C. Winston and David J. Zimmerman. All rights reserved. Short sections of text not to exceed two paragraphs, may be quoted without explicit permission provided that full credit including notice, is given to the source. 
Peer Effects in Higher Education

Gordon C. Winston and David J. Zimmerman

NBER Working Paper No. 9501

February 2003

JEL No. I21

\section{$\underline{\text { ABSTRACT }}$}

In this chapter, we describe the potential significance of student peer effects for the economic structure of and behavior in higher education. Their existence would motivate much of the restricted supply, student queuing, and selectivity - and institutional competition via merit aid and honors colleges - that we see in American higher education; their (appropriate) non-linearity could justify the resulting stratification of higher education as an efficient way to produce human capital. In addition, we use data from the College and Beyond entering class of 1989, combined with phonebook data identifying roommates, to implement a quasi-experimental empirical strategy aimed at measuring peer effects in academic outcomes. In particular, we use data on individual students' grades, SAT scores, and the SAT scores of their roommates at three schools to estimate the effect of roommates' academic characteristics on an individual's grades. The results suggest that, for two of the three schools used, students in the middle of the SAT distribution do somewhat worse in terms of grades if they share a room with a student who is in the bottom 15 percent of the SAT distribution. Students in the top of the SAT distribution appear often not to be affected by the SAT scores of their roommates. These results are similar to those reported in earlier research using data from Williams (Zimmerman) and Dartmouth (Sacerdote).

Gordon C. Williams

Department of Economics

Williams College

gwinston@williams.edu
David J. Zimmerman

Department of Economics

Williams College

david.j.zimmerman@williams.edu 


\section{Introduction}

Peer effects have played an important analytical and empirical role in studies of primary and secondary education since the Coleman Report in $1966^{1}$-- they have been used to justify busing and have entered the debates on educational costs, on tracking, and on the effects of voucher systems. ${ }^{2}$ But they have been seen as relevant to the economics of higher education only recently ${ }^{3}$ and with only a small, if growing, empirical component. $^{4}$

This chapter will address three questions: Why should we care about peer effects in examining the economics of colleges and universities? What do we know about them? And what are we learning?

\section{Peer Effects in the Economics of Higher Education}

\section{A. What Are Peer Effects?}

To begin at the beginning: Peer effects exist when a person's behavior is affected by his or her interaction with one or more other people. And those people have to be

\footnotetext{
${ }^{1}$ (Coleman, Campbell et al. 1966)

2 (U.S. Supreme Court 1971; Summers and Wolfe 1977; Hanushek 1986; Robertson and Symons 1996; Epple and Romano 1998; Lazear 1999; Hoxby 2000).

3 (Rothschild and White 1995; Winston 1995, 1999; Epple, Romano et al. 2001)

4 (Zimmerman 1999; Stinebrickner and Stinebrickner 2000; Goethals 2001; Sacerdote 2001).
} 
peers - "equals." So in higher education, peer effects result from interactions between students. $^{5}$

Peer quality is often included as an argument in an educational production function, but it's useful to put the matter even more directly as an interaction between two students,

(1) $B_{1}=f\left(B_{2}, C_{2}, X\right)$

where $B_{i}$ is behavior, $C_{i}$ is characteristics for students $i=1,2$ and $X$ is a vector of other things relevant to 1's behavior.

Then peer effects exist if the partial derivatives aren't zero and they are asymmetric or "non-linear" if those partials differ at different levels of B and C. The main empirical problem with studying peer effects, of course, is selection; that people usually choose their peers so similarities in behavior may be the result of peer effects influence - or simply selection - choice.

\section{B. Why Do We Care?}

Peer effects impact the economics of higher education in three ways:

\footnotetext{
${ }^{5}$ Peer effects among faculty (and administrators) can be important, too, of course, to recruiting, teaching, and scholarly productivity, but they are not the issue here. (Rosovsky 1990; Kennedy 1997)
} 
1. They eliminate some large and awkward anomalies in the economic behavior of colleges and universities and the economic structure of higher education as an industry, if peer effects exist.

2. They might justify as economically efficient the observed segmentation of student quality and resources - the institutional disparities we observe in American higher education - if peer effects are appropriately non-linear.

3. They lead to trade in peer quality in a market inextricably linked - blended - with that for educational services. Both of those markets and their interaction are essential to understanding pricing, admissions, and competition in higher education. $^{6}$

In the chapter, we focus on the first of these as most basic - the existence of peer effects, per se. We will examine the second - efficiency and the asymmetries in peer effects - but express our frustration because, while they are potentially important, the empirical evidence so far gives only hints about their nature. And we'll do little more than note the third - the blended markets for educational services and peer quality - since its discussion would require a chapter to itself (but see Winston, 2003).

\section{Peer Effects and Anomalies In the Higher Education Industry}

\section{$\underline{\text { A. Anomalies }}$}

At first blush, higher education looks much like a normal industry that makes a product (educational services) using purchased inputs (faculty labor, heating oil, etc...) that it sells to customers (students) for a price (tuition) in a quite competitive market. But

\footnotetext{
${ }^{6}$ (Rothschild and White 1995; Winston 2002)
} 
- Colleges charge a price that fails - significantly - to cover their production costs;

- They turn away a majority of potential customers who are willing and able to buy their product, if they can;

- they don't expand output to meet persistent excess demand, if they can avoid it;

- They lower price to attract one customer, replacing another who'd pay a higher price;

- They judge institutional quality by how many customers they can turn away and they may manipulate sales-admission policies to increase that number; ${ }^{7}$

- They require elaborate application procedures before one is allowed to make a purchase;

- They often make their customers live together, maximizing their contacts;

- They practice extensive price discrimination, not always to increase sales revenues but often to redistribute income among their customers;

- And so on.

So colleges and universities don't fit a familiar industry model - and a bad analogy can create bad policy (as it has recently, for instance, with the Justice Department and Congressional Cost Commission $^{8}$ ).

\section{B. Economic Characteristics}

${ }^{7}$ On early decision, see (Avery, Fairbanks et al. 2001; Fallows 2001).

${ }^{8}$ (US Court of Appeals 1993; National Commission on the Cost of Higher Education 1998) 
But those anomalies disappear and higher education becomes an economically coherent industry if, in fact, four economic characteristics are typical of colleges, universities, and higher education:

1 - If charitable donations significantly augment schools' commercial (sales, tuition) revenues, ${ }^{9}$

2 - If those donated resources are very unevenly distributed, supporting a hierarchy of schools based on their independence from sales revenues,

3 - If colleges and universities are less interested in profits than in a 'mission' and in 'achieving excellence or prestige,' and

4 - If, in higher education, students provide an input critical to its production - if peer effects are important to educational output.

So if these characteristics exist in higher education, they save the day - though they do call for very different economic analysis and policies. ${ }^{10}$

\section{Evidence of Those Characteristics}

What is the evidence?

\footnotetext{
${ }^{9}$ (Hansmann 1980).
}

${ }^{10}$ See (Winston 1999) 


\section{No. 1 - Donations - Non-Commercial Resources}

Certainly the first is now well established - colleges and universities charge prices that are less, a lot less, than the costs of production. A great deal of time has been spent with data from individual schools and collectively, with national (IPEDS) data for more than 2,800 colleges and universities to establish the facts in Table 1 .

The top line describes average data over all American colleges and universities in both public and private sectors in 1995-6, showing that overall, tuition (sales) revenues support only a small part of the cost of producing a student's education, the rest is covered by donations (past and present, public and private). The price/cost ratio averages 0.32 , overall, and ranges from a 0.13 average in the public sector to a 0.45 average among private schools. In a more complete analysis of IPEDS data that recognized collegiate saving, too, it appears that in a typical year, $75 \%$ of the economic resources accruing to higher education come from charitable contributions - only $25 \%$ are from commercial sales. ${ }^{11}$

\section{No. 2 - The Uneven Distribution of Donations}

The bottom part of Table 1 addresses the second characteristic, indicating how very unevenly those donations, and hence the student subsidies they support, are distributed among schools. The average student at a school in the top decile got a subsidy of $\$ 21,000$ a year - by paying $\$ 6,063$ for a $\$ 27,054$ education - while a typical

\footnotetext{
${ }^{11}$ (Winston, Carbone et al. 2001).
} 
student in a bottom decile school got only $\$ 1,700$ - paying $\$ 6,348$ for a $\$ 8,084$ education.

And decile data hide significant variation within the tails of the distribution. ${ }^{12}$

\section{No. 3 - A Non-profit Objective Function}

Though it retains its central microanalytic role, the third economic characteristic institutional values or objective function - can't be supported by data, of course. The existence, however, of decidedly non-profit behavior like need-blind admissions with need-based financial aid, along with policies like Berea College's zero tuition combined with its family income cap, certainly seem strongly to imply it. And economists Hansmann, James, Clotfelter, ${ }^{13}$ etc... -- have typically specified the objective function for a college in terms of excellence (or prestige) and mission.

\section{The Existence of Peer Effects}

The fourth characteristic is central to this chapter - if peer effects exist, they describe the incentive that schools have that leads to the stratification of students and the resulting concentration of student quality in those schools with the most non-commercial, donative resources (per student). Stratification, if peer effects exist, is the result of an efficiency wage ${ }^{14}$ in the form of student subsidy that's paid to generate a queue of applicants for a school from whom the best, in terms of the peer quality input they bring, are being selected. All schools may value the educational quality that is improved through peer effects provided by good students, but peer quality is scarce and those

\footnotetext{
${ }^{12}$ In the bottom decile are for-profit schools whose student subsidies are negative; in the top decile are those like Williams where an education that costs roughly $\$ 75,000$ to produce is sold for a sticker price of $\$ 32,470$, an average net price of $\$ 24,000$ and therefore a subsidy of about $\$ 51,000$ a year.

${ }^{13}$ (James 1978; Hansmann 1980; Clotfelter 1996).

${ }^{14}$ (Akerlof and Yellen 1986)
} 
schools that are able to pay the most for it get the most of it. The uneven distribution of those non-commercial resources creates a hierarchy that supports the stratification of student quality and motivates the long run supply restrictions on which that selectivity rests. So the existence of peer effects - in a world of uneven non-commercial revenues and institutional devotion to "excellence" - would produce the industry structure we see.

Other things, though, might motivate the same sort of highly selective structure filtering or signaling, students (or parents) getting enhanced personal utility from selection and exclusivity, per se, the satisfactions of association with the rich and famous, a marketing strategy in which schools want to emphasize that "those who have choices chose us," a self-reinforcing seeking of prestige ${ }^{15}$ - but while such a list of possibilities can be constructed, none of them implausible in itself, they are not only unsatisfyingly ad $h o c$, but they produce no socially useful outcome ${ }^{16}$ while peer effects, by enhancing learning, can increase the production of human capital. ${ }^{17}$

On the other hand, there are some familiar production externalities of student quality, aside from the peer interactions on which we're concentrating - like an instructor's ability to assign more advanced readings to better students, to give more intense and efficient lectures or to have more productive seminars - that are often thought

\footnotetext{
${ }^{15}$ (Arrow 1973; Basu 1989; James 1990; Becker 1991; Clotfelter 1996)

${ }^{16}$ Arrow is explicit: "Higher education, in this [filtering] model, contributes in no way to superior economic performance; it increases neither cognition nor socialization. Instead, higher education serves as a screening device, in that it sorts out individuals of differing abilities, thereby conveying information to the purchaser of labor... But even if (it) does have a positive informational value, it by no means follows that it is socially worthwhile" (p.199).

${ }^{17}$ Peer effects, what's more, may explain some of the educational technologies observed in higher education like residential colleges or organized study groups that increase peer interactions and hence performance. (Alexander, Gur et al. 1974; Fraser, Beamn et al. 1977)
} 
of as "peer effects" and will have the same sort of effect of making educational production a function of student quality and hence of motivating segmentation as efficient. Though they may have much the same effects, however, these externalities escape measurement when we ask, "Do peer effects exist?"

\section{Efficiency and the Asymmetry of Peer Effects}

So if peer effects exist, they can explain the segmented structure of higher education as the result of schools' bidding for peer quality inputs, the wealthy with more success than others. But, as Hoxby noted, ${ }^{18}$ the existence, per se, of peer effects may leave any regrouping of students as a largely distributional matter. Resorting students altering the stratification in higher education - would create winners and losers in the same measure under strictly linear or symmetric peer effects. But if peer effects are nonlinear - asymmetric - so students at different levels of behavior or characteristics are influenced differently by their interaction with others, then peer effects introduce an issue of economic efficiency, too. How students are grouped will affect the total amount of learning produced from given resources.

If weak students gain more from proximity to strong peers than the strong students lose from that association, then overall learning would be increased by reducing stratification - a point made a few years ago by McPherson and Schapiro in suggesting random assignment of students to colleges. ${ }^{19}$ But if asymmetries in peer effects run the other way so that strong students interacting with other strong students are also more

\footnotetext{
${ }^{18}$ (Hoxby 2000)

19 (McPherson and Schapiro 1990)
} 
sensitive to peer influence - gaining more in learning than would weak students in those same circumstances - then stratification and segmentation could increase, not decrease, aggregate learning. In the extreme, stratification would be supported on grounds of efficiency if strong students were sensitive to peer quality at all levels while weak students were unaffected by peers at any level.

Yet framing the issue as one of "strong students" and "weak students" - while it fits the empirical work that's been possible so far - misses a potentially important question of peer "distance" - how far apart the peers are in their behavior and characteristics. Is their interaction a nudge or a bludgeon? Are peer responses very different (asymmetric) outside of a "neighborhood" of proximity so a slightly different peer is influential but someone very different is not? ${ }^{20}$ It's certainly a question at the center of stratification - a strong student might typically inspire somewhat weaker peers while intimidating those more distant from her abilities. For the strong student, moderately weaker peers might represent a challenge and a chance to learn-by-teaching while much weaker peers would simply overwhelm. And numbers would play a role not captured in either our framing or our evidence - given differences and distances among peers, a student would likely respond differently to one such peer than to a whole school of them. So the shape of nonlinearities in peer effect responses would depend on both peer distance and numbers.

\footnotetext{
${ }^{20}$ This, of course, is in keeping with the Manski-Wise observation that students “... preferred to enroll in colleges where the average academic ability of the enrolled students was slightly higher than their own. Schools where the average SAT scores of entering freshmen were either too low or too high were relatively disfavored." (Manski and Wise 1983 )
} 
Finally, whatever the efficiency or inefficiency of existing stratification in producing aggregate learning, it would have to address the question recently raised with some force by Nicholas Lemann about whether those high-ability students, after learning more from their expensive educations with strong and sensitive peers, use all that learning to do anything very useful for society - whether their social marginal product justifies that selectivity. ${ }^{21}$ He argued that it doesn't.

\section{The Evidence}

\section{A. The Ideal Data}

As a transition from description of the potentially central economic role we've suggested that student peer effects might play in higher education to description of the more modest empirical results we are able to report on next, and add to, it's useful to describe the ideal data whose analysis would persuasively support that role. Inevitably, of course, the actual evidence must fall far short of perfection, but it's useful to see how and where.

Ideally, the empirical test of the existence and shape of peer effects in colleges would, in terms of equation (1) above, deal with:

- Student behavior, $\mathrm{B}_{1}$, that is centrally relevant to the purposes of higher education, broadly defined, to include, inter alia, the development of intellectual curiosity, persistence, acquisition of facts, humane values, aesthetic sensitivities, analytical and technical sophistication, social responsibility, etc.

\footnotetext{
${ }^{21}$ (Lemann 1999, 1999)
} 
- His behavior, $\mathrm{B}_{1}$, and the characteristics and behavior of his peers, $\mathrm{B}_{2}$, and $\mathrm{C}_{2}$, that were unambiguously measureable in order to investigate not only the sign of peer differences and response but also their magnitudes,

- A large population of students that generated a good deal of variation in $\mathrm{B}_{1}, \mathrm{~B}_{2}$, and $\mathrm{C}_{2}$, and their interaction, describing different distances between peers to reveal neighborhood asymmetries and non-linearities,

- Truly random assignment of associations between students that eliminated preferences in peer association, and

- Variations in peer characteristics of communities to reveal any social critical mass in conditioning peer interactions.

Data meeting these conditions would allow an effective test of the existence of peer effects and their non-linearities or asymmetries. And they would eliminate misgivings about the importance to higher education of the peer behaviors and characteristics studied so far.

Inevitably, of course, the studies described in the rest of the chapter fall short of the ideal. Though selection bias has largely been avoided through use of randomly assigned room mates and experimental groups and the results consistently show the existence of peer influences on behaviors that are relevant to education, it remains that in measuring a student's GPA response (or test scores or retention or fraternity membership) to his room mate's SATs (or income or fraternity membership), we're looking at a fairly 
thin slice of student behaviors and characteristics that leaves out a whole lot of what's happening to shape higher education.

But we find optimism in that thinness. If evidence of student peer effects can be found in so narrow a range of academic characteristics and behaviors, it's hard not to believe that with a wider and more appropriate range, they would appear with a good deal more strength. Indeed, in having to use such limited evidence for so broad an influence (and so sweeping a hypothesis), we didn't initially expect peer effects to be significantly evident. But we could neither conjure up more appropriate data nor convince ourselves that we could adequately account for selection effects in a more general population with broader behaviors. ${ }^{22}$ We were trying to see if we could find an iceberg and feel confident that we've located the tip.

But clearly, it's been easier to find evidence of the existence of peer effects than to learn much about their non-linearities. So these results do more to support the idea that peer effects help to explain industry structure and selectivity in higher education their positive role - than to support the more demanding idea that asymmetries in peer effects can justify that structure on efficiency grounds - their normative role.

\section{B. What We Have Learned So Far}

In an earlier study, one of us (Zimmerman 1999) investigated peer effects associated with a student's own grade point average and the academic strength (as measured by SAT scores) of his peers. That study attempted to overcome the selection

\footnotetext{
${ }^{22}$ Making it very difficult to document peer effects within athletic teams, for instance (Shulman 2001).
} 
bias issue by assembling a unique set of data comprised of twelve classes of students at Williams College containing information on their grades, major, gender, race, etc. along with information on where and with whom they were housed in their freshman year. ${ }^{23}$ In that paper, Zimmerman argued that freshman housing at Williams closely resembled random assignment. That being the case, it was meaningful to contrast students with high, medium, and low SAT scores who, by chance, had roommates with high, medium, or low SAT scores. This allowed, for example, comparisons between the grades of low SAT students who roomed with other low SAT roommates to the grades of low SAT students who roomed with high SAT roommates. Any differences in the outcomes could, because of the quasi-random assignment, be attributed to peer effects. The basic findings of that effort suggested that students in the middle of the SAT distribution did somewhat worse in terms of grades if they shared a room with a student who was in the bottom 15 percent of the verbal SAT distribution. Interestingly, students in the top and the bottom of the SAT distribution were not affected by the SAT scores of their (room or entry) peers. The effects, for the middle group, weren't large, but were statistically significant in many models. Furthermore, peer effects were almost always linked more strongly with verbal SAT scores than with math SAT scores.

These results, however, were estimated in the context of a highly selective liberal arts college. In that study, the "low" SAT students would, on average, still rank at about the $85^{\text {th }}$ percentile of the national SAT score distribution. The results could also have been idiosyncratic to Williams.

\footnotetext{
${ }^{23}$ See (Zimmerman forthcoming). This paper contains a broad overview of the academic literature considering peer effects
} 
Recent research has given additional support to the claim that peer effects exist in higher education (c.f. Stinebrickner and Stinebrickner 2000; Goethals 2001; Sacerdote 2001). All of these studies have examined the influence the characteristics or behavior of one student has on the behavior of another. The peer characteristics observed were, for the most part, variants on academic ability - SAT or ACT scores or more nuanced evaluations of academic promise generated in the admission process - while the influenced behavior was largely grades or performance on a written test. These characteristics were broadened to include gender and income and behaviors were broadened to include dropout behavior, choice of major, and fraternity membership.

Sacerdote (2001), using data from Dartmouth and also using a roommate-based strategy found evidence of a peer impact of a student on his roommate's grade point average as well as on his participation in fraternities. Sacerdote's results suggest a nonlinear relationship with both weaker and stronger students performing better when their roommate was in the top $25 \%$ of the academic index distribution. In addition, Sacerdote found evidence of peer effects in fraternity participation, but no evidence of peer effects in choice of college major.

Stinebrickner and Stinebrickner (2000) employed a dataset from Berea College. Like Zimmerman (1999) and Sacerdote (2001), they used the random assignment of roommates to identify the peer effect. Berea College targets low-income students (capping family income at about $\$ 65,000$ ) and so provides a useful complement to the 
highly selective schools used in the other studies. There, Stinebrickner and Stinebrickner found no evidence that either first semester grades or retention are associated with roommates' ACT scores. They did, however, find evidence that roommate income had a positive impact on both grades and retention, holding ACT scores constant, but only for women.

Goethals (2000) employed a unique and innovative experimental framework to measure peer effects. The study explored whether "students would perform better writing about newspaper articles they read and discussed in academically homogenous or heterogeneous groups of three." Interestingly, he found that students' performance was not linked to their own academic rating but was affected by whether they were placed with academically homogenous or heterogeneous peers. He found that groups composed of students who all had a low academic rating and groups composed of students who all had a high academic rating perform similarly - with both groups of these types out performing groups in which some students had high ratings and some low ratings. ${ }^{24}$ These results were stronger for men than women. So he found that peers' academic characteristics influenced others' behavior but not with straightforward non-linearities.

In sum, there is a growing - though still small - body of evidence suggesting that peer effects exist in higher education. The evidence is not clear on the nature of any nonlinearities or interactions based on gender. It also suggests that non-academic peer characteristics may also be important.

\footnotetext{
${ }^{24}$ Should these results hold up on further study, they have clear implications for sorting, stratification, and hierarchy among colleges.
} 
In this chapter we next add to the empirical evidence by employing data from the College and Beyond $(\mathrm{C} \& \mathrm{~B})$ database - created by the Andrew W. Mellon Foundation -along with matched housing data for three schools in the $\mathrm{C} \& \mathrm{~B}$ data. This allows us to apply the same empirical roommate-based approach to measuring peer effects described above. In so doing, this work adds additional evidence on the impact of peer characteristics in higher education.

\section{Empirical Strategy: New Evidence}

To estimate academic peer effects from the College and Beyond data in terms of equation (1) above, we follow the now traditional path of relating the cumulative grade point average of a student $\left(\mathrm{B}_{1}\right)$ to his own SAT scores and to the SAT scores of his first year roommate $\left(\mathrm{C}_{2}\right)$. More formally, we estimate regression models specified as:

$$
G P A_{i}=\alpha+\beta_{1} S A T_{i}+\beta_{2} S A T_{i}^{R M}+\beta_{3} X_{i}+\varepsilon_{i c}
$$

where $G P A$ is the student's Grade Point Average measured cumulatively to graduation, ${ }^{25}$ SAT is the student's own SAT score (sometimes entered separately for math and verbal scores), $S A T^{R M}$ is the student's freshman roommate's SAT score (sometimes entered separately for math and verbal scores), and $X$ is a vector of other characteristics (such as

\footnotetext{
${ }^{25}$ Grade performance for the first year, alone, was not available in C\&B data, but analysis of the Williams' data where both cumulative and freshman year GPA could be used showed that they yielded the same results (Zimmerman 1999).
} 
race, gender) of the student. ${ }^{26}$ If students are randomly assigned their roommates, then the estimated peer effect $\left(\beta_{2}\right)$ will be unbiased. More generally, the estimate will be unbiased if it is plausible that the error term is uncorrelated with the explanatory variables.

In addition, we estimate models that allow for non-linearities in the peer effect. In particular, we allow the peer effect to vary based on whether the student or his roommate is in the lowest 15 percent, the middle 70 percent, or the top 15 percent of the SAT distribution. Formally, we estimate:

$$
G P A_{i j}=\alpha+\beta_{1} S A T_{i}+\sum_{g=1}^{3} \beta_{g} S A T_{i g}^{D R M}+\beta_{3} X_{i}+\varepsilon_{i c} ; j=1,2,3
$$

where $S A T_{i g}^{D R M}$ are dummy variables for each SAT score range (indexed by $g$ ) and $\beta_{g}$ is the peer effect associated with that range.

\section{Data}

The C\&B data used in this study were created and made available to us by the Andrew Mellon foundation. The C\&B data contain both institutional and survey data for over 90,000 students enrolled in thirty-four mostly-selective colleges and universities in the United States for the entering classes of 1951, 1976, and 1989. The present study

\footnotetext{
${ }^{26}$ An appealing alternative strategy would be to include the roommate's GPA in the regression. Such a variable might better measure actual rather than potential performance. The problem with including such a variable is that it is simultaneously determined within the roommate context. Using such a measure would introduce simultaneous equation bias.
} 
uses data from three of the schools in the C\&B population for the entering class of $1989-$ for the graduating Class of '93. Institutional data in College and Beyond provide information on the students' grades, major, race, gender, etc. These data were combined with housing information extracted from college phonebooks to form a unique data set that allowed us to identify college roommates.

The schools selected for our sub-sample were chosen because a) they house their first year students together and b) the assignment mechanism of students to rooms (as indicated by their housing descriptions on the World Wide Web and conversations with their housing offices) is roughly random. It was necessary to use schools that group first year students together because the $\mathrm{C} \& \mathrm{~B}$ data do not provide information on other classes. If, for example, a school allowed first and second year students to live together we would have no information on the second year students, given C\&B's restriction to the three cohorts. Further, it is necessary for the allocation to be approximately random since selection bias can be serious when students are allowed to choose their roommates or if the housing office groups students in such a way that under- or over-performers are more likely to be housed together. In this case, the requirement that the error term be uncorrelated with the explanatory variables would be violated. In Zimmerman's earlier study of Williams freshmen (1999), he was able to utilize data from the housing application forms to conduct some relatively simple analyses to check whether the assumption of random assignment was plausible, and it was. ${ }^{27}$ The schools in this sample employed a similar protocol to that used by Williams in using housing forms indicating

\footnotetext{
27 Similarly, estimates in Sacerdote (2001) were unaffected by the inclusion of housing preference variables.
} 
sleep preferences, smoking behavior, etc. in assigning students to rooms/roommates though the underlying housing form data were not obtained. ${ }^{28}$

\section{Empirical Results}

Table 2 provides summary statistics for the sample. The number of observations for the samples from the three schools ranged from 1,458 to 2,116 . SAT scores ranged from a low of 360 on the verbal test and 420 on the math test to a maximum of 800 on both tests. The average combined SAT score ranged from 1344 to 1409 . These scores are high, putting the average student in the top 10 percent of the population of test takers. Each school had between 7\% and 9\% African American students and 2\%-5\% Hispanic students.

Table 3 presents estimates of equation (2). The results for each school are reported in a separate column where a student's cumulative grade point average is regressed on his own SAT score (divided by 100), race, gender, major, and roommate's SAT score. The model includes controls for a student's major (which is selected in his or her junior year) to provide some control for grade differentials arising from students' taking different courses (Sabot 1991).

\footnotetext{
${ }^{28}$ See (Zimmerman forthcoming) for a mathematical model that illustrates the possibility of bias in the estimated peer effects flowing from the use of housing forms in assigning students to rooms. Chi-squared tests indicate that we cannot reject independence between the SAT scores of roommates for schools \#1 and $\# 3$ in the sample. For school \#2 independence is rejected. The rejection is driven by a somewhat high fraction of low SAT students living together and a somewhat low fraction of low SAT students living with high SAT students. The distribution of low, medium, and high students is as expected under independence for the middle SAT students. In total, there are about 100 of the 2116 students that show signs of selection.
} 
The effect of a student's own SAT score is large and statistically significant, with each 100 point increase resulting in between a .116 and a .132 increase in grade point average. After controlling for SAT scores, black and Hispanic students score between a quarter and a third of a grade point below white students. Female students score between .082 and .127 grade points higher than male students. Finally, roommate's SAT score is found to have a positive and statistically significant effect only for School \#2 - where a 100 point increase in a student's roommate's combined SAT score translates into a .02 increase in the student's own grade point average. This effect is about 17 percent as large as that of a 100 point increment in the student's own SAT score. ${ }^{29}$

Tables 4, 6, and 8 report estimates of equation (3) allowing the peer effect to depend on the student's own position in the SAT distribution. Panel A allows us to see whether weak, average, or strong students (as measured by their SAT scores) are more, or less, affected by roommates. The results in these panels suggest that strong students at all three schools are unaffected by the SAT scores of their roommates. Students in the bottom $15 \%$ of the SAT distribution benefit from higher SAT scoring roommates at School \#1 - though not at schools 2 and 3. Students in the middle 70 percent of the distribution are unaffected by the SAT scores of their roommates at Schools 1 and 3 though they benefit from higher scoring roommates at School \#2. Students in the middle 70 percent of the SAT distribution at School \#2 experience, on average, a .02 increase in their cumulative GPA when their roommates' SAT scores increase by 100 points.

\footnotetext{
${ }^{29}$ It is worth noting here that models allowing for differential effects for math and verbal SAT scores were also estimated, but standard F-tests indicated no measurable difference in their impact. Accordingly, only models using combined SAT scores are reported.
} 
Panel B allows the peer effect to be nonlinear. That is, it allows us to see whether weak, average, or strong students (as measured by their SAT scores) are more, or less, affected by having roommates who are weak, average, or strong in terms of their combined SAT scores. For this model, at School \#1, we find low SAT students performing somewhat worse when roomed with a similarly weak peer. The coefficient shows grades for this group would increase by .156 points if they had a high SAT room mate. The coefficient is significant at the ten percent level. At School \#2, neither the strongest nor the weakest students are affected by the SAT scores of their roommates. Students in the middle $70 \%$ of the SAT distribution, however, perform somewhat worse when their roommates are in the bottom $15 \%$ of the SAT distribution. The estimates suggest that a student in this part of the SAT distribution, with a bottom $15 \%$ roommate, would, on average, have a cumulative GPA that is lower by .086 points than that of a similar student whose roommate was in the top $15 \%$ of the SAT distribution. Similar results are found at School \#3 where, in addition, there is evidence that the strongest students perform better when their roommates are academically stronger. It is worth noting that these results are robust to moderate variations in the percentile cutoffs used to define the groups.

Tables 5, 7, and 9 report estimates of equation (3) separately for men and women. Perhaps due to smaller sample sizes, peer effects are not statistically significant for most groups. Exceptions are found at Schools \#2 and \#3. At School \#2, male students in the middle of the SAT distribution are found to perform worse when their roommate is in the 
lowest $15 \%$ of the SAT distribution; at School \#3, academically strong women perform better when given academically strong peers.

Table 10 presents estimates using data stacked for the three schools. School fixed effects are included in these models. The main advantage of stacking the data is that there are larger cell sizes - giving us more precise estimates -- with which to gauge any non-linearities. These results are presented pooled by gender and also separately for male and female students. The results mirror those above with students in the middle showing lower grades if their roommate is in the bottom $15 \%$ of the SAT distribution. The estimates suggest that this result is driven by the male sample - as the coefficients for women are not significant for any of the SAT groups. There is also some evidence again particularly for men - that strong students perform somewhat worse if their roommate is in the middle of the SAT distribution rather than in the top.

To put the myriad results in context it is useful to summarize the existing research more succinctly. The research to date, including the evidence reported in this paper, on the effect of peer academic characteristics on a "grade type" outcome, is summarized in the Table 11.

These studies differ in a variety of ways: the selectivity of the school surveyed, the measurement and detection of non-linearities, the outcome considered, the existence of differences by gender, and so on. The evidence found thus far suggests that the existence of peer effects at the most basic level has been confirmed in each of the studies. 
Sacerdote (2001) finds that grades are higher when students have unusually academically strong roommates. Zimmerman $(1999,2001)$ finds that weak peers might reduce the grades of middling or strong students. Stinebrickner finds that peer ACT scores are insignificant after controlling for roommate family income, which is significant. Goethals finds that homogeneity per se matters - students perform better when grouped with others of like ability.

\section{Conclusion and Agenda}

Evidence on peer effects in higher education now exists at the most basic level for six colleges and universities - covering some 12,000 students - with interactions measured for randomly assigned roommates and participants in psych lab experiments. It seems clear that peer effects exist - that students' characteristics and behavior do, indeed, influence other students' behavior with conventionally measured academic characteristics (like SAT) influencing conventionally measured academic performance (like GPA).

New evidence presented in this chapter adds to our confidence that peer effects exist and that the signs of those effects are in the direction that would motivate institutional selectivity - strong students tend to increase peers' academic performance and weak students tend to reduce it. Combined with a sharply skewed distribution of resources across colleges, the broad question, "Can peer effects in educational production help explain the unusual economic structure and behavior of higher education?" is answered, 
"Yes." The models, of Winston (1999) and Epple-Romano-Sieg (2001) -- data-driven and formally derived respectively -- fit both the data and the peer effect evidence. ${ }^{30}$

But beyond that key question, the facts become less clear and the agenda for investigation of peer effects becomes larger. So there are often different results by gender, as in Hoxby's K-12 results (2000), even in these data that rest on individual interactions rather than on those between groups. On non-linearities - whether peer influences operate equally and symmetrically across characteristics and behaviors - the evidence is puzzling with homogeneous groupings - strong or weak - sometimes performing significantly better than those with peers of different abilities. Students of middling ability are usually more susceptible to peer influence than those at either end of the ability distribution (keeping in mind that the student populations reported on here represent very narrow ability ranges). And since our data are based on pairwise interactions, a similar analysis might well be extended to those interactions that are electronically mediated to see if a "distance learning" environment generates any evidence of peer effects.

The range of peer characteristics and behaviors should be extended, too, wherever possible. The work reported here sticks, by and large, to the most measurable and obvious aspects of education - grade performance and academic ability - with occasional departure into fraternity membership, family income, and dropout behavior. But while

\footnotetext{
30 Note that there's no evidence of a "teaching effect" in which strong students gain from association with weaker students whom they can teach (as implied by Zajonc's analysis of older siblings (1976)) nor is there strong evidence of an "intimidation effect," though that might help explain Goethals' finding that weak students do better when grouped with other weak students.
} 
these are clearly the right place to start, they capture a small part of the behaviors influenced by higher education and of interest to colleges in their selection of student peer quality - it may be possible to get closer to our "ideal data" with other measurable academic behaviors among randomly associated peers. Like Heckman (1999), Bowles, Gintis and Osborn (2001) point out that a small part of the variance in wages attributable to education is explained by the cognitive skills we measure with tests and GPAs - the rest is attributable to behaviors learned before, after, in, and outside of school that may escape cognitive measurement but influence job performance, nonetheless, like reliability, attitude, discipline, fatalism, impatience, etc. To the extent that these characteristics and behaviors can be identified and measured, they need to be included in studies of peer effects in higher education. ${ }^{31}$

So we conclude that evidence on the existence of peer effects in higher education is strong, consistent with an understanding of its economic structure - selectivity, skewed resources, and the resulting stratification - that relies on them, but that there remains a rich set of questions on how and how broadly peer effects operate among students in colleges $^{32}$ and especially on the shape of the non-linearities that would help us evaluate that structure.

\footnotetext{
${ }^{31}$ On the basis of evidence that a student's impatience (his time-discount behavior) influences his own academic performance (students with lower discount rates get better grades, holding SATs constant (Kirby, Winston et al. 2002)), we tried, in a very small sample, to find evidence of peer influence such that one roommate's discount rate affected the other's academic performance. But while the sign of the relationship was right, it was decidedly insignificant.

${ }^{32}$ Nor has our discussion even touched on negative peer effects like binge drinking and date rape.
} 
Table 1

The Distribution of Average Cost, Price and Student Subsidies

1996

\begin{tabular}{cccc} 
& $\begin{array}{c}\text { Subsidy } \\
\text { per Student }\end{array}$ & $\begin{array}{c}\text { Average } \\
\text { Educational } \\
\text { Cost }\end{array}$ & $\begin{array}{c}\text { Average } \\
\text { Net } \\
\text { Tuition }\end{array}$ \\
\cline { 1 - 4 } All Colleges and Universities & & & \\
Public & $\$ 8,423$ & $\$ 12,413$ & $\$ 3,989$ \\
Private & $\$ 8,590$ & $\$ 9,896$ & $\$ 1,305$ \\
& $\$ 8,253$ & $\$ 14,986$ & $\$ 6,734$ \\
Schools ranked by & & & \\
Student Subsidies: & & & \\
Decile 1 & & & \\
Decile 2 & $\$ 20,991$ & $\$ 27,054$ & $\$ 6,063$ \\
Decile 3 & $\$ 1,865$ & $\$ 15,801$ & $\$ 3,936$ \\
Decile 4 & $\$ 10,009$ & $\$ 13,310$ & $\$ 3,301$ \\
Decile 5 & $\$ 8,752$ & $\$ 11,831$ & $\$ 3,080$ \\
Decile 6 & $\$ 7,855$ & $\$ 10,565$ & $\$ 2,710$ \\
Decile 7 & $\$ 7,020$ & $\$ 9,820$ & $\$ 2,799$ \\
Decile 8 & $\$ 6,250$ & $\$ 9,464$ & $\$ 3,214$ \\
Decile 9 & $\$ 5,447$ & $\$ 8,848$ & $\$ 3,401$ \\
Decile 10 & $\$ 4,262$ & $\$ 9,297$ & $\$ 5,035$ \\
& $\$ 1,736$ & $\$ 8,084$ & $\$ 6,348$
\end{tabular}

Source: Based on US Department of Education IPEDS data. Includes 2791 institutions, of which 1411 are public and 1380 are private. All dollar amounts are per FTE student averaged over institutions. See Winston (2000) and Winston-Yen (1995) for details on the derivation of these data from the IPEDS Finance Survey (Medical schools are omitted here). 
Table 2: Descriptive Statistics

\begin{tabular}{|c|c|c|c|c|}
\hline School \#1 & Mean & Standard Deviation & Minimum & Maximum \\
\hline Sample Size & 1863 & 0 & 1863 & 1863 \\
\hline Own SAT Score - Verbal & 714 & 66 & 420 & 800 \\
\hline Own SAT Score - Math & 695 & 69 & 480 & 800 \\
\hline Own SAT Score - Combined & 1409 & 112 & 1090 & 1600 \\
\hline Black & .079 & .270 & 0 & 1 \\
\hline Hispanic & .052 & .223 & 0 & 1 \\
\hline Native American & .004 & .069 & 0 & 1 \\
\hline Asian & .151 & .358 & 0 & 1 \\
\hline Not a Citizen of the United States & .03 & .169 & 0 & 1 \\
\hline Female & .432 & .495 & 0 & 1 \\
\hline School \#2 & .430 & .494 & 0 & 1 \\
\hline Sample Size & 2116 & 0 & 2116 & 2116 \\
\hline Own SAT Score - Verbal & 668 & 68 & 360 & 800 \\
\hline Own SAT Score - Math & 676 & 68 & 450 & 800 \\
\hline Own SAT Score - Combined & 1344 & 110 & 950 & 1600 \\
\hline Black & .086 & .282 & 0 & 1 \\
\hline Hispanic & .044 & .206 & 0 & 1 \\
\hline Native American & N/A & N/A & N/A & N/A \\
\hline Asian & .160 & .367 & 0 & 1 \\
\hline Not a Citizen of the United States & .095 & .292 & 0 & 1 \\
\hline Female & .430 & .494 & 0 & 1 \\
\hline School \#3 & Mean & Standard Deviation & Minimum & Maximum \\
\hline Sample Size & 1458 & 0 & 1458 & 1458 \\
\hline Own SAT Score - Verbal & 687 & 61 & 450 & 800 \\
\hline Own SAT Score - Math & 681 & 68 & 420 & 800 \\
\hline Own SAT Score - Combined & 1368 & 106 & 880 & 1600 \\
\hline Black & .072 & .258 & 0 & 1 \\
\hline Hispanic & .022 & .148 & 0 & 1 \\
\hline Native American & .001 & .036 & 0 & 1 \\
\hline Asian & .079 & .270 & 0 & 1 \\
\hline Not a Citizen of the United States & .03 & .148 & 0 & 1 \\
\hline Female & .466 & .499 & 0 & 1 \\
\hline
\end{tabular}


Table 3: Your Grades and Your Roommate's SAT Scores

\begin{tabular}{|c|c|c|c|}
\hline & $\begin{array}{l}\text { Cumulative GPA } \\
\text { (School\#1) }\end{array}$ & $\begin{array}{l}\text { Cumulative GPA } \\
(\text { School \#2) }\end{array}$ & $\begin{array}{l}\text { Cumulative GPA } \\
(\text { School\#3) }\end{array}$ \\
\hline Own SAT Score/100 & $\begin{array}{l}0.131 \\
(0.01)\end{array}$ & $\begin{array}{l}.116 \\
(.013)\end{array}$ & $\begin{array}{l}.132 \\
(.012)\end{array}$ \\
\hline Black & $\begin{array}{l}-.264 \\
(.068)\end{array}$ & $\begin{array}{l}-.306 \\
(.060)\end{array}$ & $\begin{array}{l}-.380 \\
(.054)\end{array}$ \\
\hline Hispanic & $\begin{array}{l}-.172 \\
(.085)\end{array}$ & $\begin{array}{l}-.080 \\
(.055)\end{array}$ & $\begin{array}{l}.005 \\
(.046)\end{array}$ \\
\hline Native American & $\begin{array}{l}-.268 \\
(.157)\end{array}$ & N/A & $\begin{array}{l}.145 \\
(.071)\end{array}$ \\
\hline Not a Citizen of the United States & N/A & $\begin{array}{l}-.047 \\
(.065)\end{array}$ & N/A \\
\hline Asian & $\begin{array}{l}-.011 \\
(.031)\end{array}$ & $\begin{array}{l}-.071 \\
(.031)\end{array}$ & $\begin{array}{l}-.033 \\
(.042)\end{array}$ \\
\hline Female & $\begin{array}{l}.127 \\
(.028)\end{array}$ & $\begin{array}{l}.082 \\
(.024)\end{array}$ & $\begin{array}{l}.112 \\
(.024)\end{array}$ \\
\hline Major Dummy Variables & YES & YES & YES \\
\hline Roommates SAT Score/100 & $\begin{array}{l}0.013 \\
(0.007)\end{array}$ & $\begin{array}{l}0.020 \\
(0.008)\end{array}$ & $\begin{array}{l}.013 \\
(.009)\end{array}$ \\
\hline Sample Size & 1863 & 2116 & 1458 \\
\hline R-Squared & .303 & 0.215 & 0.2475 \\
\hline
\end{tabular}

Note: Standard Errors are corrected for correlation within roommate cluster. Bolded peer and own SAT coefficients are significant at the 10\% level. 
Table 4: Your Grades and Your Roommate's SAT Scores by SAT Group School \#1 (Dependent Variable is Cumulative GPA)

\begin{tabular}{|c|c|c|c|}
\hline & $\begin{array}{l}\text { Combined SAT } \\
\text { Score (lowest } 15 \% \text { ) }\end{array}$ & $\begin{array}{l}\text { Combined SAT Score } \\
\text { (middle } 70 \% \text { ) }\end{array}$ & $\begin{array}{l}\text { Combined SAT Score } \\
\text { (top 15\%) }\end{array}$ \\
\hline \multicolumn{4}{|l|}{ A. Linearity in Roommates Scores } \\
\hline Own SAT Score - Verbal/100 & $\begin{array}{l}.065 \\
(.087)\end{array}$ & $\begin{array}{l}.223 \\
(.029)\end{array}$ & $\begin{array}{l}.036 \\
(.124)\end{array}$ \\
\hline Own SAT Score - Math/100 & $\begin{array}{l}.024 \\
(127)\end{array}$ & .172 & $\begin{array}{l}.124 \\
(148)\end{array}$ \\
\hline \multirow[t]{2}{*}{ Black } & -.174 & $-\left(\begin{array}{ll}0.0307 \\
-.297\end{array}\right.$ & -.758 \\
\hline & $(.186)$ & $(.079)$ & $(.165)$ \\
\hline Hispanic & .0402 & $\begin{array}{l}-.311 \\
(142)\end{array}$ & -.024 \\
\hline Native American & $\begin{array}{l}-.045 \\
(.160)\end{array}$ & $\begin{array}{l}-.356 \\
(.251)\end{array}$ & (dropped) \\
\hline Not a Citizen of the United States & $\mathrm{N} / \mathrm{A}$ & $\mathrm{N} / \mathrm{A}$ & N/A \\
\hline Asian & $\begin{array}{l}.226 \\
.230)\end{array}$ & $\begin{array}{l}-.004 \\
(.039)\end{array}$ & $\begin{array}{l}-.040 \\
(.052)\end{array}$ \\
\hline Female & $\begin{array}{l}.233 \\
(.110)\end{array}$ & $\begin{array}{l}.138 \\
(.032)\end{array}$ & $\begin{array}{l}.012 \\
(.056)\end{array}$ \\
\hline Major Dummy Variables & YES & YES & YES \\
\hline Roommates SAT Score/100 & $\begin{array}{l}.032 \\
(.010)\end{array}$ & $\begin{array}{l}.011 \\
(.008) \\
1281\end{array}$ & $\begin{array}{l}-.009 \\
(.014)\end{array}$ \\
\hline \multirow[t]{2}{*}{ R- Squared } & 0.288 & 0.295 & 0.154 \\
\hline & $\begin{array}{l}\text { Combined SAT } \\
\text { Score (lowest 15\%) }\end{array}$ & $\begin{array}{l}\text { Combined SAT Score } \\
\text { (middle } 70 \% \text { ) }\end{array}$ & $\begin{array}{l}\text { Combined SAT Score } \\
\text { (top } 15 \% \text { ) }\end{array}$ \\
\hline \multicolumn{4}{|l|}{ B. Non-linearity in Roommates Scores } \\
\hline Own SAT Score - Verbal/100 & $\begin{array}{l}.060 \\
(.089)\end{array}$ & $\begin{array}{l}.223 \\
(.02856)\end{array}$ & $\begin{array}{l}.021 \\
.125\end{array}$ \\
\hline Own SAT Score - Math/100 & $\begin{array}{l}.021 \\
(.128)\end{array}$ & $\begin{array}{l}.172 \\
(.033)\end{array}$ & $\begin{array}{l}.100 \\
(.151)\end{array}$ \\
\hline Black & $\begin{array}{l}-.175 \\
(.183)\end{array}$ & $\begin{array}{l}-.297 \\
(.079)\end{array}$ & $\begin{array}{l}-.805 \\
(.163)\end{array}$ \\
\hline Hispanic & $\begin{array}{l}.043 \\
(.086)\end{array}$ & $\begin{array}{l}-.312 \\
(.141)\end{array}$ & $\begin{array}{l}.1022 \\
(.114)\end{array}$ \\
\hline Native American & $\begin{array}{l}-.075 \\
(.169\end{array}$ & $\mid \begin{array}{l}-.352 \\
(.251)\end{array}$ & (dropped) \\
\hline Not a Citizen of the United States & $\mathrm{N} / \mathrm{A}$ & N/A & $\mathrm{N} / \mathrm{A}$ \\
\hline Asian & $\begin{array}{l}.233 \\
(.231)\end{array}$ & $\begin{array}{l}-.004 \\
(.039)\end{array}$ & $\begin{array}{l}-.039 \\
(.051)\end{array}$ \\
\hline Female & $\begin{array}{l}.220 \\
(.110)\end{array}$ & $\begin{array}{l}.137 \\
(.032)\end{array}$ & $\begin{array}{l}.022 \\
(.055)\end{array}$ \\
\hline Major Dummy Variables & YES & YES & YES \\
\hline Roommates SAT Score - Lowest $15 \%$ & $\begin{array}{l}-.156 \\
(.086)\end{array}$ & $\begin{array}{l}-.044 \\
(.032)\end{array}$ & $\begin{array}{l}-.002 \\
(.050)\end{array}$ \\
\hline Roommates SAT Score - Middle 70\% & $\begin{array}{l}-.131 \\
(.085)\end{array}$ & $\begin{array}{l}-.023 \\
(.025)\end{array}$ & $\begin{array}{l}-.038 \\
(.043)\end{array}$ \\
\hline Sample Size & 269 & 1281 & 313 \\
\hline R- Squared & 0.295 & 0.295 & 0.154 \\
\hline
\end{tabular}

Note: Standard Errors are corrected for correlation within roommate cluster. Bolded peer and own SAT coefficients are significant at the $10 \%$ level. 
Table 5: Your Grades and Your Roommate's SAT Scores by SAT Group and Gender - School \#1 (Dependent Variable is Cumulative GPA)

\begin{tabular}{|c|c|c|c|}
\hline & $\begin{array}{l}\text { Combined SAT Score } \\
\text { (lowest } 15 \%)\end{array}$ & $\begin{array}{l}\text { Combined SAT Score } \\
\text { (middle 70\%) }\end{array}$ & $\begin{array}{l}\text { Combined SAT Score } \\
\text { (top 15\%) }\end{array}$ \\
\hline \multicolumn{4}{|l|}{ A. Men } \\
\hline Own SAT Score - Verbal/100 & $\begin{array}{l}.048 \\
(.108)\end{array}$ & $\begin{array}{l}.266 \\
(.034)\end{array}$ & $\mid \begin{array}{l}-.006 \\
(.172)\end{array}$ \\
\hline Own SAT Score - Math/100 & $\begin{array}{l}.113 \\
(.122)\end{array}$ & $\begin{array}{l}.163 \\
(.043)\end{array}$ & $\begin{array}{l}-.002 \\
(.002)\end{array}$ \\
\hline Black & $\begin{array}{l}.041 \\
(.124)\end{array}$ & $\begin{array}{l}-.438 \\
(.132)\end{array}$ & $\begin{array}{l}-.817 \\
(.206)\end{array}$ \\
\hline Hispanic & $\begin{array}{l}.067 \\
(.096)\end{array}$ & $\begin{array}{l}-.128 \\
(.134)\end{array}$ & $\begin{array}{l}.006 \\
.091)\end{array}$ \\
\hline Native American & (dropped) & $\begin{array}{l}-.717 \\
(.254)\end{array}$ & (dropped) \\
\hline Not a Citizen of the United States & N/A & $\mathrm{N} / \mathrm{A}$ & N/A \\
\hline Asian & $\begin{array}{l}.926 \\
(.220)\end{array}$ & $\begin{array}{l}.039 \\
(.056)\end{array}$ & $\begin{array}{l}-.075 \\
(.112)\end{array}$ \\
\hline Major Dummy Variables & YES & YES & YES \\
\hline Roommates SAT Score - Lowest $15 \%$ & $\begin{array}{l}-.167 \\
(.117)\end{array}$ & $\begin{array}{l}-.054 \\
(.046)\end{array}$ & $\begin{array}{l}.078 \\
(.060)\end{array}$ \\
\hline Roommates SAT Score - Middle 70\% & $\begin{array}{l}-.108 \\
(.088)\end{array}$ & $\begin{array}{l}-.042 \\
(.035)\end{array}$ & $\begin{array}{l}-.022 \\
(.033)\end{array}$ \\
\hline Sample Size & 137 & 739 & 187 \\
\hline \multirow[t]{2}{*}{ R- Squared } & 0.637 & 0.323 & 0.309 \\
\hline & $\begin{array}{l}\text { Combined SAT Score } \\
\text { (lowest } 15 \%)\end{array}$ & $\begin{array}{l}\text { Combined SAT Score } \\
\text { (middle } 70 \%)\end{array}$ & $\begin{array}{l}\text { Combined SAT Score } \\
\text { (top 15\%) }\end{array}$ \\
\hline \multicolumn{4}{|l|}{ B. Women } \\
\hline Own SAT Score - Verbal/100 & $\begin{array}{l}.117 \\
(.166)\end{array}$ & $\begin{array}{l}.187 \\
(.057)\end{array}$ & $\begin{array}{l}-.101 \\
(.182)\end{array}$ \\
\hline Own SAT Score - Math/100 & $\begin{array}{l}-.062 \\
(.200)\end{array}$ & $\begin{array}{l}.192 \\
(.046)\end{array}$ & $\begin{array}{l}.095 \\
(.227)\end{array}$ \\
\hline Black & $\begin{array}{l}-.436 \\
(.347)\end{array}$ & $\begin{array}{l}-.228 \\
(.085)\end{array}$ & (dropped) \\
\hline Hispanic & $\begin{array}{l}-.057 \\
(.161)\end{array}$ & $\begin{array}{l}-.474 \\
(.251)\end{array}$ & (dropped) \\
\hline Native American & $\begin{array}{l}-.242 \\
(.185)\end{array}$ & $\begin{array}{l}-.064 \\
(.130)\end{array}$ & (dropped) \\
\hline Not a Citizen of the United States & $\mathrm{N} / \mathrm{A}$ & $\mathrm{N} / \mathrm{A}$ & N/A \\
\hline Asian & $\begin{array}{l}.105 \\
(.149)\end{array}$ & $\begin{array}{l}-.073 \\
(.052)\end{array}$ & $\begin{array}{l}-.040 \\
(.086)\end{array}$ \\
\hline Major Dummy Variables & YES & YES & YES \\
\hline Roommates SAT Score - Lowest $15 \%$ & $\begin{array}{l}-.104 \\
(.124)\end{array}$ & $\begin{array}{l}-.026 \\
(.040)\end{array}$ & $\begin{array}{l}-.020 \\
(.084)\end{array}$ \\
\hline Roommates SAT Score - Middle 70\% & $\begin{array}{l}-.143 \\
(.124)\end{array}$ & $\begin{array}{l}-.006 \\
(.034)\end{array}$ & $\begin{array}{l}.028 \\
(.101)\end{array}$ \\
\hline Sample Size & 132 & 543 & 128 \\
\hline R- Squared & 0.279 & 0.325 & 0.441 \\
\hline
\end{tabular}

Note: Standard Errors are corrected for correlation within roommate cluster.

Bolded peer and own SAT coefficients are significant at the $10 \%$ level. 
Table 6: Your Grades and Your Roommate's SAT Scores by SAT Group School \#2 (Dependent Variable is Cumulative GPA)

\begin{tabular}{|c|c|c|c|}
\hline & $\begin{array}{l}\begin{array}{l}\text { Combined SAT Score } \\
(\text { lowest } 15 \%)\end{array} \\
\end{array}$ & $\begin{array}{l}\text { Combined SAT Score } \\
\text { (middle } 70 \%)\end{array}$ & $\begin{array}{l}\text { Combined SAT Score } \\
\text { (top } 15 \% \text { ) }\end{array}$ \\
\hline \multicolumn{4}{|l|}{ A. Linearity in Roommates Scores } \\
\hline Own SAT Score - Verbal/100 & $\begin{array}{l}.162 \\
(.088)\end{array}$ & $\begin{array}{l}.142 \\
(.025)\end{array}$ & $\begin{array}{l}-.109 \\
(.098)\end{array}$ \\
\hline Own SAT Score - Math/100 & $\begin{array}{l}.077 \\
(.101)\end{array}$ & $\begin{array}{l}.166 \\
(.027)\end{array}$ & $\begin{array}{l}.063 \\
(.112)\end{array}$ \\
\hline Black & $\begin{array}{l}-.235 \\
(079)\end{array}$ & $\begin{array}{l}-.341 \\
(085)\end{array}$ & -.117 \\
\hline Hispanic & $\begin{array}{l}(.076) \\
-.036 \\
(.127)\end{array}$ & $\begin{array}{l}(.0060 \\
-.060 \\
(.070)\end{array}$ & $\begin{array}{l}(.071) \\
-.071 \\
(.095)\end{array}$ \\
\hline Native American & N/A & $\mathrm{N} / \mathrm{A}$ & $\mathrm{N} / \mathrm{A}$ \\
\hline Not a Citizen of the United States & $\begin{array}{l}-.204 \\
(.243)\end{array}$ & $\begin{array}{l}-.016 \\
(.079)\end{array}$ & $\begin{array}{l}.026 \\
(.065)\end{array}$ \\
\hline Asian & $\begin{array}{l}.102 \\
(.145)\end{array}$ & $\begin{array}{l}-.083 \\
(.033)\end{array}$ & $\begin{array}{l}-.111 \\
(.081)\end{array}$ \\
\hline Female & $\begin{array}{l}.067 \\
(.077)\end{array}$ & & $\begin{array}{l}-.109 \\
(.129)\end{array}$ \\
\hline Major Dummy Variables & YES & YES & YES \\
\hline $\begin{array}{l}\text { Roommates SAT Score/100 } \\
\text { Sample Size }\end{array}$ & $\begin{array}{l}.017 \\
(.021) \\
280\end{array}$ & $\begin{array}{l}.020 \\
(.009) \\
1500\end{array}$ & $\begin{array}{l}.0438 \\
(.026) \\
336\end{array}$ \\
\hline \multirow[t]{2}{*}{ R-Squared } & 0.286 & 0.181 & 0.178 \\
\hline & $\begin{array}{l}\begin{array}{l}\text { Combined SAT Score } \\
\text { (lowest } 15 \%)\end{array} \\
\end{array}$ & $\begin{array}{l}\text { Combined SAT Score } \\
\text { (middle } 70 \%)\end{array}$ & $\begin{array}{l}\text { Combined SAT Score } \\
\text { (top } 15 \% \text { ) }\end{array}$ \\
\hline \multicolumn{4}{|l|}{ B. Non-linearity in Roommates Scores } \\
\hline Own SAT Score - Verbal/100 & $\begin{array}{l}.167 \\
(.088)\end{array}$ & $\begin{array}{l}.143 \\
(.025)\end{array}$ & $\begin{array}{l}-.110 \\
(.098)\end{array}$ \\
\hline Own SAT Score - Math/100 & $\begin{array}{l}.088 \\
(.100)\end{array}$ & $\begin{array}{l}.166 \\
(.027)\end{array}$ & $\begin{array}{l}.059 \\
(.111)\end{array}$ \\
\hline Black & $\begin{array}{l}-.238 \\
(.079)\end{array}$ & $\begin{array}{l}-.340 \\
(.085)\end{array}$ & $\begin{array}{l}-.086 \\
(.168)\end{array}$ \\
\hline $\begin{array}{l}\text { Hispanic } \\
\text { Native American }\end{array}$ & $\begin{array}{l}-.035 \\
(.127) \\
\mathrm{N} / \mathrm{A}\end{array}$ & $\begin{array}{l}-.050 \\
(.069) \\
\mathrm{N} / \mathrm{A}\end{array}$ & $\begin{array}{l}-.055 \\
(.102) \\
\mathrm{N} / \mathrm{A}\end{array}$ \\
\hline Not a Citizen of the United States & $\begin{array}{l}-.174 \\
(.242)\end{array}$ & $\begin{array}{l}-.009 \\
(.078)\end{array}$ & $\begin{array}{l}-.109 \\
(.128)\end{array}$ \\
\hline Asian & $\begin{array}{l}.108 \\
(.142)\end{array}$ & $\begin{array}{l}-.082 \\
(.033)\end{array}$ & $\begin{array}{l}-.110 \\
(.081)\end{array}$ \\
\hline Female & $\begin{array}{l}.061 \\
(.077)\end{array}$ & $\begin{array}{l}.102 \\
(.026)\end{array}$ & $\begin{array}{l}.015 \\
(.064)\end{array}$ \\
\hline Major Dummy Variables & YES & YES & YES \\
\hline Roommates SAT Score - Lowest $15 \%$ & $\begin{array}{l}-.042 \\
(.088)\end{array}$ & $\begin{array}{l}-.086 \\
(.034)\end{array}$ & $\begin{array}{l}-.099 \\
(.102)\end{array}$ \\
\hline Roommates SAT Score - Middle 70\% & $\begin{array}{l}-.066 \\
(.072)\end{array}$ & $\begin{array}{l}-.022 \\
(.023)\end{array}$ & $\begin{array}{l}-.079 \\
(.057)\end{array}$ \\
\hline Sample Size & 282 & 1505 & 337 \\
\hline R- Squared & 0.286 & 0.181 & 0.172 \\
\hline
\end{tabular}

Note: Standard Errors are corrected for correlation within roommate cluster. Bolded peer and own SAT coefficients are significant at the $10 \%$ level. 
Table 7: Your Grades and Your Roommate's SAT Scores by SAT Group and Gender - School \#2 (Dependent Variable is Cumulative GPA)

\begin{tabular}{|c|c|c|c|}
\hline & $\begin{array}{l}\text { Combined SAT Score } \\
\text { (lowest } 15 \% \text { ) }\end{array}$ & $\begin{array}{l}\text { Combined SAT Score } \\
\text { (middle } 70 \% \text { ) }\end{array}$ & $\begin{array}{l}\text { Combined SAT Score } \\
\text { (top } 15 \% \text { ) }\end{array}$ \\
\hline \multicolumn{4}{|l|}{ A. Men } \\
\hline Own SAT Score - Verbal/100 & $\begin{array}{l}.230 \\
(.166)\end{array}$ & $\begin{array}{l}.194 \\
(.034)\end{array}$ & $\left(\begin{array}{l}-.164 \\
(.114)\end{array}\right.$ \\
\hline Own SAT Score - Math/100 & $\begin{array}{l}.105 \\
(.165)\end{array}$ & $\begin{array}{l}.212 \\
(.038)\end{array}$ & $\begin{array}{l}.038 \\
(.127)\end{array}$ \\
\hline Black & $\begin{array}{l}-.239 \\
(.187)\end{array}$ & $\begin{array}{l}-.281 \\
(.131)\end{array}$ & (dropped) \\
\hline Hispanic & $\left(\begin{array}{l}-.134 \\
(.233)\end{array}\right.$ & $\begin{array}{l}.055 \\
(.077)\end{array}$ & $\begin{array}{l}-.087 \\
(.112)\end{array}$ \\
\hline Native American & $\mathrm{N} / \mathrm{A}$ & $\mathrm{N} / \mathrm{A}$ & N/A \\
\hline Not a Citizen of the United States & $\begin{array}{l}-.068 \\
(.377)\end{array}$ & $\begin{array}{l}.027 \\
(.093)\end{array}$ & $\begin{array}{l}-.163 \\
(.141)\end{array}$ \\
\hline Asian & $\begin{array}{l}.188 \\
(.270)\end{array}$ & $\begin{array}{l}-.053 \\
(.048)\end{array}$ & $\begin{array}{l}-.166 \\
(.112)\end{array}$ \\
\hline Major Dummy Variables & YES & YES & YES \\
\hline Roommates Verbal SAT Score - Lowest 15\% & $\begin{array}{l}-.132 \\
(.194)\end{array}$ & $\begin{array}{l}-.132 \\
(.056)\end{array}$ & $\begin{array}{l}-.092 \\
(.121)\end{array}$ \\
\hline Roommates Verbal SAT Score - Middle 70\% & $\begin{array}{l}-.093 \\
(.109)\end{array}$ & $\begin{array}{l}-.036 \\
(.029)\end{array}$ & $\begin{array}{l}-.082 \\
(.068)\end{array}$ \\
\hline Sample Size & 110 & 839 & 245 \\
\hline \multirow[t]{2}{*}{ R- Squared } & 0.258 & 0.209 & 0.238 \\
\hline & $\begin{array}{l}\text { Combined SAT Score } \\
\text { (lowest } 15 \%)\end{array}$ & $\begin{array}{l}\text { Combined SAT Score } \\
\text { (middle 70\%) }\end{array}$ & $\begin{array}{l}\text { Combined SAT Score } \\
\text { (top } 15 \% \text { ) }\end{array}$ \\
\hline \multicolumn{4}{|l|}{ B. Women } \\
\hline Own SAT Score - Verbal/100 & $\begin{array}{l}.126 \\
(.094)\end{array}$ & $\begin{array}{l}.074 \\
(.041)\end{array}$ & $\begin{array}{l}.093 \\
(.179)\end{array}$ \\
\hline Own SAT Score - Math/100 & $\begin{array}{l}.165 \\
(.123)\end{array}$ & $\begin{array}{l}.118 \\
(.040)\end{array}$ & $\begin{array}{l}.119 \\
(.269)\end{array}$ \\
\hline Black & $\begin{array}{l}-.226 \\
(.083)\end{array}$ & $\begin{array}{l}-.375 \\
(.113)\end{array}$ & $\begin{array}{l}-.477 \\
(.166)\end{array}$ \\
\hline Hispanic & $\begin{array}{l}.046 \\
(.124)\end{array}$ & $\begin{array}{l}-.273 \\
(.116)\end{array}$ & (dropped) \\
\hline Native American & $\mathrm{N} / \mathrm{A}$ & $\mathrm{N} / \mathrm{A}$ & N/A \\
\hline Not a Citizen of the United States & $\begin{array}{l}-.358 \\
(.403)\end{array}$ & $\begin{array}{l}-.087 \\
(.070)\end{array}$ & (dropped) \\
\hline Asian & $\begin{array}{l}.030 \\
(.133)\end{array}$ & $\begin{array}{l}-.102 \\
(.048)\end{array}$ & $\begin{array}{l}-.065 \\
(.145)\end{array}$ \\
\hline Major Dummy Variables & YES & YES & YES \\
\hline Roommates SAT Score - Lowest 15\% & $\begin{array}{l}.102 \\
(.112)\end{array}$ & $\begin{array}{l}-.014 \\
(.043)\end{array}$ & $\begin{array}{l}.139 \\
(.129)\end{array}$ \\
\hline Roommates SAT Score - Middle 70\% & $\begin{array}{l}.072 \\
(.095)\end{array}$ & $\begin{array}{l}.022 \\
(.036)\end{array}$ & $\begin{array}{l}-.018 \\
(.080)\end{array}$ \\
\hline Sample Size & 172 & 666 & 92 \\
\hline R- Squared & 0.439 & 0.204 & 0.209 \\
\hline
\end{tabular}

Note: Standard Errors are corrected for correlation within roommate cluster. Bolded peer and own SAT coefficients are significant at the $10 \%$ level. 
Table 8: Your Grades and Your Roommate's SAT Scores by SAT Group School \#3 (Dependent Variable is Cumulative GPA)

\begin{tabular}{|c|c|c|c|}
\hline & $\begin{array}{l}\begin{array}{l}\text { Combined SAT Score } \\
\text { (lowest } 15 \%)\end{array} \\
\end{array}$ & $\begin{array}{l}\begin{array}{l}\text { Combined SAT Score } \\
\text { (middle } 70 \%)\end{array} \\
\end{array}$ & $\begin{array}{l}\text { Combined SAT Score } \\
\text { (top } 15 \% \text { ) }\end{array}$ \\
\hline \multicolumn{4}{|l|}{ A. Linearity in Roommates Scores } \\
\hline Own SAT Score - Verbal/100 & $\begin{array}{l}.214 \\
.061)\end{array}$ & $\begin{array}{l}.114 \\
(.032)\end{array}$ & $\begin{array}{l}.183 \\
(.085)\end{array}$ \\
\hline Own SAT Score - Math/100 & $\begin{array}{l}.146 \\
(.065)\end{array}$ & .101 & $\begin{array}{l}.236 \\
(.106)\end{array}$ \\
\hline Black & $\begin{array}{l}-.309 \\
(.082)\end{array}$ & $\begin{array}{l}-.498 \\
(.112)\end{array}$ & $\begin{array}{l}-.186 \\
(.076)\end{array}$ \\
\hline Hispanic & $\begin{array}{l}.028 \\
(.086)\end{array}$ & $\begin{array}{l}-.021 \\
(.064)\end{array}$ & $\begin{array}{l}.191 \\
(.131)\end{array}$ \\
\hline Native American & (dropped) & $\begin{array}{l}.120 \\
(.087)\end{array}$ & (dropped) \\
\hline Not a Citizen of the United States & $\mathrm{N} / \mathrm{A}$ & $\mathrm{N} / \mathrm{A}$ & N/A \\
\hline Asian & $\begin{array}{l}.310 \\
(.164)\end{array}$ & $\begin{array}{l}-.097 \\
(.049)\end{array}$ & $\begin{array}{l}.045 \\
(.090)\end{array}$ \\
\hline Female & $\begin{array}{l}.108 \\
(.078)\end{array}$ & $\begin{array}{l}.088 \\
(.030)\end{array}$ & $\begin{array}{l}.122 \\
(.068)\end{array}$ \\
\hline Major Dummy Variables & YES & YES & YES \\
\hline Roommates SAT Score/100 & $\begin{array}{l}-.016 \\
(.025) \\
221\end{array}$ & $\begin{array}{l}.019 \\
(.011) \\
975\end{array}$ & $\begin{array}{l}.036 \\
(.026) \\
262\end{array}$ \\
\hline \multirow[t]{2}{*}{ R- Squared } & 0.3560 & $(0.1151)$ & 0.1215 \\
\hline & $\begin{array}{l}\text { Combined SAT Score } \\
\text { (lowest } 15 \%)\end{array}$ & $\begin{array}{l}\text { Combined SAT Score } \\
\text { (middle } 70 \% \text { ) }\end{array}$ & $\begin{array}{l}\text { Combined SAT Score } \\
\text { (top } 15 \% \text { ) }\end{array}$ \\
\hline \multicolumn{4}{|l|}{ B. Non-linearity in Roommates Scores } \\
\hline Own SAT Score - Verbal/100 & $\begin{array}{l}.207 \\
.056)\end{array}$ & $\begin{array}{l}.114 \\
.032)\end{array}$ & $\begin{array}{l}.186 \\
(.083)\end{array}$ \\
\hline Own SAT Score - Math/100 & $\begin{array}{l}.148 \\
(.065)\end{array}$ & $\begin{array}{l}.100 \\
(.031)\end{array}$ & $\begin{array}{l}.238 \\
(.102)\end{array}$ \\
\hline Black & $\begin{array}{l}-.303 \\
(.078)\end{array}$ & $\begin{array}{l}-.498 \\
(.111)\end{array}$ & $\begin{array}{l}-.145 \\
(.079)\end{array}$ \\
\hline Hispanic & $\begin{array}{l}.031 \\
(.082)\end{array}$ & $\begin{array}{l}-.014 \\
(.059)\end{array}$ & $\begin{array}{l}.193 \\
(.116)\end{array}$ \\
\hline Native American & (dropped) & $\begin{array}{l}.110 \\
(.085)\end{array}$ & (dropped) \\
\hline Not a Citizen of the United States & N/A & $\mathrm{N} / \mathrm{A}$ & N/A \\
\hline Asian & $\begin{array}{l}.314 \\
(.165)\end{array}$ & $\begin{array}{l}-.094 \\
(.049)\end{array}$ & $\begin{array}{l}.058 \\
(.090)\end{array}$ \\
\hline Female & $\begin{array}{l}.110 \\
(.078)\end{array}$ & $\begin{array}{l}.090 \\
(.030)\end{array}$ & $\begin{array}{l}.139 \\
(.066)\end{array}$ \\
\hline Major Dummy Variables & YES & YES & YES \\
\hline Roommates SAT Score - Lowest $15 \%$ & $\begin{array}{l}.069 \\
(.096)\end{array}$ & $\begin{array}{l}-.092 \\
(.041)\end{array}$ & $\begin{array}{l}-.175 \\
(.077)\end{array}$ \\
\hline Roommates SAT Score - Middle $70 \%$ & $\begin{array}{l}.004 \\
(.081)\end{array}$ & $\begin{array}{l}-.038 \\
(.031)\end{array}$ & $\begin{array}{l}-.127 \\
(.061)\end{array}$ \\
\hline Sample Size & 223 & 981 & 263 \\
\hline R- Squared & 0.3585 & 0.1173 & 0.1377 \\
\hline
\end{tabular}

Note: Standard Errors are corrected for correlation within roommate cluster.

Bolded peer and own SAT coefficients are significant at the $10 \%$ level. 
Table 9: Your Grades and Your Roommate's SAT Scores by SAT Group and Gender - School \#3 (Dependent Variable is Cumulative GPA)

\begin{tabular}{|c|c|c|c|}
\hline & $\begin{array}{l}\text { Combined SAT Score } \\
\text { (lowest } 15 \%)\end{array}$ & $\begin{array}{l}\text { Combined SAT Score } \\
\text { (middle 70\%) }\end{array}$ & $\begin{array}{l}\text { Combined SAT Score } \\
\text { (top } 15 \% \text { ) }\end{array}$ \\
\hline \multicolumn{4}{|l|}{ A. Men } \\
\hline Own SAT Score - Verbal/100 & $\begin{array}{l}.079 \\
(.073)\end{array}$ & $\begin{array}{l}.136 \\
(.048)\end{array}$ & $\mid \begin{array}{l}.154 \\
(.099)\end{array}$ \\
\hline Own SAT Score - Math/100 & $\begin{array}{l}.255 \\
(.105)\end{array}$ & $\begin{array}{l}.174 \\
(.049)\end{array}$ & $\begin{array}{l}.176 \\
(.134)\end{array}$ \\
\hline Black & $-(.261)$ & $\begin{array}{l}-.632 \\
(.159)\end{array}$ & $\begin{array}{l}-.077 \\
(.077)\end{array}$ \\
\hline Hispanic & & $\begin{array}{l}-.170 \\
(.087)\end{array}$ & \\
\hline Native American & (dropped) & $\begin{array}{l}.043 \\
(.088)\end{array}$ & (dropped) \\
\hline Not a Citizen of the United States & N/A & $\mathrm{N} / \mathrm{A}$ & N/A \\
\hline Asian & $\begin{array}{l}.236 \\
(.219)\end{array}$ & $\begin{array}{l}-.158 \\
(.071)\end{array}$ & $\begin{array}{l}-.008 \\
(.105)\end{array}$ \\
\hline Major Dummy Variables & YES & YES & YES \\
\hline Roommates Verbal SAT Score - Lowest 15\% & $\begin{array}{l}.161 \\
(.120)\end{array}$ & $\begin{array}{l}-.085 \\
(.069)\end{array}$ & $\begin{array}{l}-.107 \\
(.093)\end{array}$ \\
\hline Roommates Verbal SAT Score - Middle 70\% & $\begin{array}{l}.105 \\
(.112)\end{array}$ & $\begin{array}{l}-.063 \\
(.045)\end{array}$ & $\begin{array}{l}-.107 \\
(.063)\end{array}$ \\
\hline Sample Size & 104 & 464 & 204 \\
\hline \multirow[t]{2}{*}{ R- Squared } & 0.4625 & 0.1634 & 0.1396 \\
\hline & $\begin{array}{l}\text { Combined SAT Score } \\
(\text { lowest } 15 \%)\end{array}$ & $\begin{array}{l}\begin{array}{l}\text { Combined SAT Score } \\
\text { (middle } 70 \%)\end{array} \\
\end{array}$ & $\begin{array}{l}\begin{array}{l}\text { Combined SAT Score } \\
\text { (top } 15 \% \text { ) }\end{array} \\
\end{array}$ \\
\hline \multicolumn{4}{|l|}{ B. Women } \\
\hline Own SAT Score - Verbal/100 & $\begin{array}{l}.292 \\
(.081)\end{array}$ & $\begin{array}{l}.110 \\
(.044)\end{array}$ & $\begin{array}{l}.460 \\
(.127)\end{array}$ \\
\hline Own SAT Score - Math/100 & $\begin{array}{l}.200 \\
(.098)\end{array}$ & $\begin{array}{l}.031 \\
(.039)\end{array}$ & \\
\hline Black & {$\left[\begin{array}{l}-.192 \\
(.107)\end{array}\right.$} & $\begin{array}{l}-.377 \\
(.135)\end{array}$ & $\begin{array}{l}-.335 \\
(.055)\end{array}$ \\
\hline $\begin{array}{l}\text { Hispanic } \\
\text { Native American }\end{array}$ & $\begin{array}{l}.0190 \\
(.145) \\
\text { (dropped) }\end{array}$ & $\begin{array}{l}.070 \\
(.073) \\
(\text { dropped) }\end{array}$ & $\begin{array}{l}.429 \\
(.233) \\
(\text { dropped) }\end{array}$ \\
\hline Not a Citizen of the United States & N/A & N/A & N/A \\
\hline $\begin{array}{l}\text { Asian } \\
\text { Major Dummy Variables }\end{array}$ & $\begin{array}{l}.128 \\
(.150) \\
\text { YES }\end{array}$ & $\begin{array}{l}-.050 \\
(.072) \\
\text { YES }\end{array}$ & $\begin{array}{l}.212 \\
(.084) \\
\text { YES }\end{array}$ \\
\hline Roommates SAT Score - Lowest $15 \%$ & $\begin{array}{l}.018 \\
(.179)\end{array}$ & $\begin{array}{l}-.059 \\
(.048)\end{array}$ & $\begin{array}{l}-.266 \\
(.133)\end{array}$ \\
\hline Roommates SAT Score - Middle 70\% & $\begin{array}{l}-.124 \\
(.114)\end{array}$ & $\begin{array}{l}.003 \\
(.039)\end{array}$ & $\begin{array}{l}-.149 \\
(.076)\end{array}$ \\
\hline Sample Size & 119 & 517 & 59 \\
\hline R- Squared & 0.4546 & 0.1172 & 0.6660 \\
\hline
\end{tabular}

Note: Standard Errors are corrected for correlation within roommate cluster. Shaded peer and own SAT coefficients are significant at the $10 \%$ level. 
Table 10: Peer Coefficients from Stacked Data for All Three Schools (Dependent Variable is Cumulative GPA)

\begin{tabular}{|c|c|c|c|}
\hline & $\begin{array}{l}\text { Combined SAT Score } \\
\text { (lowest } 15 \% \text { ) }\end{array}$ & $\begin{array}{l}\text { Combined SAT Score } \\
\text { (middle } 70 \% \text { ) }\end{array}$ & $\begin{array}{l}\text { Combined SAT Score } \\
\text { (top } 15 \% \text { ) }\end{array}$ \\
\hline A. Men and Women & & & \\
\hline Roommates SAT Score - Lowest 15\% & $\begin{array}{l}-.070 \\
(.057)\end{array}$ & $\begin{array}{l}-.067 \\
(.021)\end{array}$ & $\mid \begin{array}{l}-.063 \\
(.044)\end{array}$ \\
\hline Roommates SAT Score - Middle 70\% & $\begin{array}{l}-.073 \\
(.050)\end{array}$ & $\begin{array}{l}-.029 \\
(.015)\end{array}$ & $\begin{array}{l}-.066 \\
(.030)\end{array}$ \\
\hline B. Men & & & \\
\hline Roommates SAT Score - Lowest 15\% & $\begin{array}{l}-.004 \\
(.088)\end{array}$ & $\begin{array}{l}-.077 \\
(.031)\end{array}$ & $\begin{array}{l}-.029 \\
(.062)\end{array}$ \\
\hline Roommates SAT Score - Middle $70 \%$ & $\begin{array}{l}-.042 \\
(.068)\end{array}$ & $\begin{array}{l}-.044 \\
(.020)\end{array}$ & $\begin{array}{l}-.067 \\
(.035)\end{array}$ \\
\hline C. Women & & & \\
\hline $\begin{array}{l}\text { Roommates SAT Score - Lowest } 15 \% \\
\text { Roommates SAT Score - Middle 70\% }\end{array}$ & $\begin{array}{l}-.091 \\
(.075) \\
-.101 \\
(.078) \\
\end{array}$ & $\begin{array}{l}-.036 \\
(.027) \\
.006 \\
(.022) \\
\end{array}$ & $\begin{array}{l}-.062 \\
(.057) \\
-.021 \\
(.055) \\
\end{array}$ \\
\hline
\end{tabular}

Note: Bolded peer SAT coefficients are significant at the $10 \%$ level. Other controls are own SAT scores, gender, ethnicity, major, and school fixed effect. 
Table 11 : Recent Studies of Academic Peer Effects

\begin{tabular}{|l|l|l|l|}
\hline Academic Peer Effects & \multicolumn{2}{|l|}{$\begin{array}{l}\text { Coefficient } \\
\text { on grades }\end{array}$} & Comments \\
\hline $\begin{array}{l}\text { Zimmerman } \\
(1999)\end{array}$ & $\begin{array}{l}\text { Roommate's Verbal } \\
\text { SAT in bottom 15\% }\end{array}$ & $\begin{array}{l}-.077 \\
(.027)\end{array}$ & $\begin{array}{l}\text { Impact on middle 70\% of SAT } \\
\text { distribution, Williams College }\end{array}$ \\
\hline $\begin{array}{l}\text { Zimmerman } \\
\text { (as reported } \\
\text { in this } \\
\text { chapter) }\end{array}$ & $\begin{array}{l}\text { Roommate's Verbal } \\
\text { SAT in bottom 15\% }\end{array}$ & $\begin{array}{l}-.086 \\
(.034)\end{array}$ & $\begin{array}{l}\text { Impact on middle 70\% of SAT } \\
\text { distribution, three schools from } \\
\text { College and Beyond. }\end{array}$ \\
\hline $\begin{array}{l}\text { Sacerdote } \\
(2001)\end{array}$ & $\begin{array}{l}\text { Roommate in top } \\
\text { 25\% of Academic } \\
\text { Rating Index }\end{array}$ & $\begin{array}{l}.060 \\
(.028)\end{array}$ & $\begin{array}{l}\text { Dartmouth. Controls for housing } \\
\text { questions. Also peer effect on } \\
\text { fraternity membership but none on } \\
\text { major. }\end{array}$ \\
\hline $\begin{array}{l}\text { Stinebrickner } \\
\text { and } \\
\text { Stinebrickner } \\
(2001)\end{array}$ & ACT score & $\begin{array}{l}\text { Controls for roommate's family } \\
\text { income. Roommate income is } \\
\text { significant with grades, rising .052 } \\
\text { per \$10,000 income, for women. }\end{array}$ \\
\hline $\begin{array}{l}\text { Goethals } \\
(2000)\end{array}$ & $\begin{array}{l}\text { Admissions office } \\
\text { academic rating }\end{array}$ & $\begin{array}{l}\text { Finds performance increases with } \\
\text { group homogeneity in academic } \\
\text { rating. }\end{array}$ \\
\hline $\begin{array}{l}\text { Taken from Table 4 in Zimmerman (1999), Table 3 in Sacerdote (2000), Table 3 in } \\
\text { Stinebrickner (2000) and Tables 5 to 10 above. }\end{array}$
\end{tabular}




\section{REFERENCES:}

(1971). Swann v. Charlotte-Mecklenburg Board of Education. 402 U.S. 1, US Supreme Court. 28: 554.

(1993). United States v. Brown University. F.3d 658: 1993 U.S. App. LEXIS 23895, United States Court of Appeals for the Third District.

Akerlof, G. A. and J. L. Yellen (1986). Introduction. Efficiency Wage Models of the Labor Market. Akerlof-Yellen, Cambridge: Cambridge University Press.

Alexander, L., R. Gur, et al. (1974). "Peer Assisted Learning.” Improving Human Performance Quaterly 3(4): 175-186.

Arrow, K. J. (1973). "Higher Education as a Filter." Journal of Public Economics 2: 193216.

Avery, C., A. Fairbanks, et al. (2001). What Worms for the Early Bird? Early Admissions at Selective Colleges.

Basu, K. (1989). “A Theory of Association: Social Status, Prices and Markets.” Oxford Economic Papers 41: 653-670.

Becker, G. S. (1991). "A Note on Restaurant Pricing and Other Examples of Social Influences on Price.” Journal of Political Economy 99: 1109-16.

Bowles, S., H. Gintis, et al. (2001). "The Determinants of Earnings: A Behavioral Approach.” Journal of Economic Literature XXXIX(4): 1137-1176.

Clotfelter, C. T. (1996). Buying the Best: Cost Escalation in Elite Higher Education. Princeton, Princeton University Press.

Coleman, J. S., E. Q. Campbell, et al. (1966). Equality of Educational Opportunity. Washington DC, Office of Education, US Department of Health, Education, and Welfare.

Epple, D., R. Romano, et al. (2001). Peer Effects, Financial Aid, and Selection of Students into Colleges and Universities: An Empirical Analysis.

Epple, D. and R. E. Romano (1998). "Competition Between Private and Public Schools, Vouchers, and Peer-Group Effects.” American Economic Review 88(1): 33-62.

Fallows, J. (2001). "The Early-Decision Racket." The Atlantic Monthly 288(2): 37-52.

Fraser, S., A. Beamn, et al. (1977). "Two, Three, or Four Heads are better than One: Modification of College Performance by Peer Monitoring." Journal of Educational Psychology 69(2): 101-108.

Goethals, G. R. (2001). Peer Effects, Gender and Intellectual Performance Among Students at a Highly Selective College: a Social Comparison of Abilities Analysis. Williamstown, MA, The Williams Project on the Economics of Higher Education.

Hansmann, H. (1980). "The Role of Nonprofit Enterprise.” The Yale Law Journal 89(5): 835-901.

Hanushek, E. (1986). "The Economics of Schooling: Production and Efficiency in Public Schools." Journal of Economic Literature 24(3): 1141-1177.

Heckman, J. J. (1999). "Doing it right: job training and education.” Public Interest. Hoxby, C. M. (2000). Peer Effects in the Classroom: Learning from Gender and Race Variation. Cambridge, MA, National Bureau of Economic Research.

James, E. (1978). "Product Mix and Cost Disaggregation: A Reinterpretation of the Economics of Higher Education.” Journal of Human Resources XII(2): 157-186. 
James, E. (1990). Decision Processes and Priorities in Higher Education. The Economics of American Universities. Buffalo, New York, State University of New York Press.

Kennedy, D. (1997). Academic Duty. Cambridge, Harvard University Press.

Kirby, K. N., G. C. Winston, et al. (2002). Impatience and Grades: Delay-Discount Rates Correlate Negatively with College GPA. Williamstown, MA, The Williams Project on the Economics of Higher Education.

Lazear, E. P. (1999). Educational Production. Cambridge, MA, NBER.

Lemann, N. (1999). The Big Test: The Secret History of the American Meritocracy. New York, Ferrar, Straus \& Giroux, Inc.

Lemann, N. (1999). The Kids in the Conference Room: How McKinsey \& Company Becme the Next Big Step. The New Yorker: 209-216.

Manski, C. F. and D. A. Wise (1983). College Choice in America. Cambridge, Harvard University Press.

McPherson, M. S. and M. O. Schapiro (1990). Selective Admission and the Public Interest. New York, The College Board Press.

National Commission on the Cost of Higher Education (1998). Straight Talk About College Costs and Prices: Report of the National Commission on the Cost of Higher Education. Phoenix, The Oryx Press.

Robertson, D. and J. Symons (1996). Do Peer Groups Matter? Peer Group versus Schooling Effects on Academic Attainment, London School of Economics Centre for Economic Performance, Discussion Paper.

Rosovsky, H. (1990). The University: An Owner's Manual. New York, W.W. Norton \& Company.

Rothschild, M. and L. J. White (1995). "The Analytics of Pricing in Higher Education and Other Services in Which Customers are Inputs." Journal of Political Economy 103.

Sabot, R., J. Wakeman-Linn. (1991). "The Implications of Grading Policies for Student Course Choice." Journal of Economic Perspectives Vol. 5(No. 1): 159-170.

Sacerdote, B. (2001). "Peer Effects with Random Assignment: Results for Dartmouth Roommates." Quarterly Journal of Economics.

Shulman, J. L., and William G. Bowen (2001). The Game of Life: College Sports and Educational Values. Princeton, Princeton University Press.

Stinebrickner, T. R. and R. Stinebrickner (2000). Peer Effects Among Students From Disadvantaged Backgrounds.

Summers, A. A. and B. L. Wolfe (1977). "Do Schools Make a Difference?" American Economic Review LXVII(67): 639-652.

Winston, G. C. (1999). "Subsidies, Hierarchy, and Peers: The Awkward Economics of Higher Education." The Journal of Economic Perspectives 13.

Winston, G. C. (2003). "Toward a Theory of Tuition: Prices, Peer Wages, and Competition in Higher Education. Williamstown, MA, The Williams Project on the Economics of Higher Education.

Winston, G. C., and Ivan C. Yen (1995). Costs, Prices, Subsidies, and Aid in U.S. Higher Education, Williams Project on the Economics of Higher Education. 
Winston, G. C., J. C. Carbone, et al. (2001). Saving, Wealth, Performance, and Revenues in US Colleges and Universities. Williamstown MA, The Williams Project on the Economics of Higher Education.

Zajonc, R. B. (1976). "Family configuration and intelligence." Science 192: 227-36.

Zimmerman, D. J. (1999). Peer Effects in Academic Outcomes: Evidence from a Natural Experiment. Williamstown, MA, The Williams Project on the Economics of Higher Education.

Zimmerman, D. J. (forthcoming). "Peer Effects in Academic Outcomes: Evidence from a Natural Experiment." Review of Economics and Statistics. 